\title{
Time and Cost Overruns on Large Projects: Understanding the Root Cause
}

\author{
"Sitwala Simushi' and Jan Wium²
}

\begin{abstract}
Published online: 15 July 2020
To cite this article: Sitwala Simushi and Jan Wium (2020). Time and cost overruns on large projects: Understanding the root cause. Journal of Construction in Developing Countries, 25(1): 129-146. https://doi.org/10.21315/jcdc2020.25.1.7.
\end{abstract}

To link to this article: https://doi.org/10.21315/jcdc2020.25.1.7

\begin{abstract}
Time and cost overruns are a persistent problem on large projects despite apparent progress of the project management profession. This article reports on findings from research carried out on large projects in South Africa to find the root cause of this phenomenon. The article begins by investigating the existing theories on the causes of time and cost overruns followed by empirical investigation using case studies. The results showed that time and cost overruns on large projects originated from the external environment which in turn affected the organisation and the project environments. The root cause was found to be a lack of project-specific experience by the project team, external and organisational decisions in the past, community resistance and pressure on the project team and scope change drive from stakeholders. From the results, it is proposed that an effective strategy to reduce time and cost overruns should involve not only the management of the project environment but also the organisation and external environments. The article adds knowledge to the overrun causation theory and management of large projects.
\end{abstract}

Keywords: Overruns, Root cause, Large projects, South Africa, Overrun causation theory

\section{INTRODUCTION}

The recurrent problem of time and cost overruns on large projects has been noted by many scholars over the years (Dahl et al., 2017; Merrow, 2011 ; Morris and Hough, 1987; Mukuka, Aigbavboa and Thwala, 2015; Senouci, Ismail and Eldin, 2016). Most scholars have attempted to understand this phenomenon by investigating singular, independent causes or most significant factors that lead to time and cost overruns. Few have attempted to understand in-depth, how time and cost overruns develop in large projects (Love et al., 2014), or the interaction of the various variables leading to time and cost overruns as noted by Ahiaga-Dagbui et al. (2015).

There is, therefore, an incomplete theory and understanding of the phenomenon of time and cost overruns (Love, Ahiaga-Dagbui and Irani, 2016) as conventional research has tended to use research methods which are ill-suited for an in-depth understanding of the actuality of managing projects (AISehaimi, Koskela and Tzortzopoulos, 2013). The methods are dependent on the general opinions of the practitioners, unlike project-specific and contextual reality of projects, thus making them superficial, simplistic and mostly replicative as noted by Ahiaga-Dagbui et al. (2015). This has, in turn, affected the approach to project management strategies and solutions proposed.

\footnotetext{
'School of Built Environment, Copperbelt University, ZAMBIA ${ }^{2}$ Faculty of Engineering, Stellenbosch University, SOUTH AFRICA

*Corresponding author: simushis@yahoo.com
} 
This research aimed to investigate the root cause of time and cost overruns on large projects. The article presents the findings from investigations on several large projects. The article adds knowledge to the overrun causation theory and management of large projects.

\section{LITERATURE REVIEW}

Large projects are generally defined either from the characteristics or the financial value of the project (see Capka, 2004; Lin and Lui, 2011; Murray, 2010; Tai and Anumba, 2009; Whittaker, 1999). In this research, a large project is defined as a project that is complex in terms of project delivery, involves several stakeholders and supply chains, with a large scale of funding of more than USD30 million.

The problem of time and cost overruns is persistent on construction projects (Cantarelli et al., 2012). For large projects, due to the impact on a national economy, the problem is magnified (Capka, 2004). Various causes of time and cost overruns have been given in the literature. It is difficult to determine which factors are the most important as each scholar had their way of presenting data (Ramanathan, Narayanan and Idrus, 2012). Furthermore, few have attempted to put up a theory or theories to explain overrun causation. Love et al. (2016), after reviewing the literature, suggested two predominant theories on overrun causation, based on discussions of scholars over the years, which are evolution theory and psycho-strategy theory.

In the evolution theory, whose proponents are in the majority, it is believed that overruns are due to scope and definition change from what was planned at inception. Eizakshiri, Chan and Emsely (2011) criticised this view because it does not question the accuracy of the schedule and cost plan initiated at the beginning.

Another theory, related to the evolution theory, is that overruns are due to poor project management practice both at the planning and execution stages as suggested by AISehaimi, Koskela and Tzortzopoulos (2013). This can be seen in the work of Frimpong, Oluwoye and Crawford (2003) and Le-Hoai, Lee and Lee (2008) where inaccurate time and cost estimates and, poor project management are identified as major causes of time and cost overruns. Despite this theory, the question would still be asked, what is it that is leading to ineffective planning and control of projects? Or, why do the project teams deviate from the planned objectives? This theory, therefore, does not provide a complete explanation of what causes time and cost overruns.

In the psycho-strategy theory, proposed by Flyvbjerg (2011), it is said that overruns are a result of inaccurate estimates and project plans due to optimism bias and strategic misrepresentation by the people preparing estimates and projects at the beginning, to get project acceptance. This theory answers the question of why estimates and plans are inaccurate.

Other schools of thought are that of "pathogens" and "cost growth" (AhiagaDagbui and Smith, 2014). The first theory is that there are many intermediate events and actions called "pathogens" such as errors which, unaccounted for at project estimate build-up, remain latent but drive up costs later. The other theory is that "cost growth" is a natural phenomenon because projects evolve due to changes in scope, design and leadership which affect the initial aims, scope, skills and competence of the project team later. This is still the evolution theory but viewed 
from the angle of acceptance that change is inevitable, which unfortunately does not move towards a solution but acceptance of the inevitability of change.

Merrow (2011) found that poor performance on large projects was largely due to lack of critical project management competencies at the front end in the client's organisation as was also observed by Anderson and Merna (2003) that often there was poor strategy formulation at the beginning. Sweis (2013), in his research of Jordanian public construction projects, found that three significant factors lead to time and cost overruns: poor qualifications of consultants, engineers and staff assigned to the project, severe weather conditions and poor planning and scheduling by the contractor. The first two are factors external to the project team of client, consultant and contractor. The last is a factor in the project team, the contractor.

Rosenfield (2013) on his part, broke down the root cause of cost overruns to systemic causes, project-related causes and organisational causes. For instance, under organisational causes, there was insufficient, unstandardised owner's brief and too small a design budget. What were the causes of these factors? Why were the budgets too small? The author did not probe further.

These studies show that apart from causes related to the client, the contractor and the consultant, other factors lead to time and cost overruns in the management of large projects which include decisions in the higher levels of the client's organisation and the training and experience of consultants and staff engaged in projects. This, therefore, suggests that the evolution and the psychostrategy theories of overrun causation may not provide a complete understanding of how overruns are caused, particularly in large projects.

Some scholars have indicated other factors external to the microenvironment as leading causes of time and cost overruns: Kaliba, Muya and Mumba (2009) identified bad weather, inflation and environmental mitigation measures, Ameh, Soyingbe and Odusami (2010) found environmental factors such as economy, inadequate raw materials and competition, Memon et al. (2014) found fluctuations of materials and shortage of site workers while Muianga, Granja and Ruiz (2014) found government, environment and economy, shortage of materials and equipment and, fluctuations of materials and equipment.

Morris and Geraldi (2011) in recommending improvement in the management of projects, proposed that project management should be thought in terms of three levels: (1) Level 1 - A technical level which is concerned with operating and effective delivery of the project on time, budget and scope, (2) Level 2 - Strategic level concerned with managing projects as organisational entities to include the front-end and (3) Level 3 - Institutional context to create context and conditions for projects to flourish within the organisation and outside. Lim and Mohamed (1999) had earlier proposed viewing project success from the micro and macro project perspectives. These being those participants involved in the project and those of all other stakeholders not directly involved respectively.

In this research, building on the work of Morris and Geraldi (2011) and Lim and Mohamed (1999), a project is viewed as performed in three environments: (1) The project environment, being the environment in which the participants operate in, which include individuals and organisations concerned with the production of the solution such as the project manager, the consultant and the contractor, (2) The organisation environment, which combines Level 2 and 3 of Morris and Geraldi (2011) being the milieu in which the project is defined, directed and managed. It principally includes the structures and levels of the client's organisation, and 
(3) The external environment or the macro environment, where activities and processes outside the organisation and the project environment take place which affects the operations of the project. These could include societal environments such as the legal system, culture, community groups, the media and the political system. The project and organisation environments are part of the microproject environment and they directly affect the project.

\section{RESEARCH METHOD}

The multiple case study method was adopted for this study as it encourages in-depth investigation using extreme or deviant and typical cases (Fellows and Lui, 2008; Harding, 2013). A total of five cases were identified starting with a typical overrunning project. The results were validated using literal and theoretical replication case studies of two other overrunning projects and two non-overrunning projects. See Table 1 for a case study summary.

Table 1. Characteristics of the Case Studies

\begin{tabular}{|c|c|c|c|}
\hline Case Study & Project Description & Project Type & Research \\
\hline Case Study I & Stadium construction & Public & $\begin{array}{l}\text { The typical overrunning } \\
\text { project study }\end{array}$ \\
\hline Case Study II & Power plant construction & Public & Literal replication study \\
\hline Case Study III & $\begin{array}{l}\text { High-speed rail } \\
\text { construction }\end{array}$ & $\begin{array}{l}\text { Public/ } \\
\text { private }\end{array}$ & Literal replication study \\
\hline Case Study IV & Dam construction & Public & $\begin{array}{l}\text { Theoretical replication } \\
\text { study }\end{array}$ \\
\hline Case Study V & $\begin{array}{l}\text { Commercial building } \\
\text { construction }\end{array}$ & Private & $\begin{array}{l}\text { Theoretical replication } \\
\text { study }\end{array}$ \\
\hline
\end{tabular}

The two successful cases were studied together with the overrunning cases not only to verify the observations from the overrunning cases but also to aid in finding a solution to the observed problem. The two successful cases gave the concept for the strategy recommended in the article.

A combination of interviews, observation and documentary analysis techniques were used to collect data in a triangulation of research methods to improve the validity and reliability of the results (Yin, 2014). The interviews were transcribed and analysed using thematic analysis, theoretical propositions and explanation building (see Harding, 2013) following the sequential approach where results from the typical case study were analysed, theoretical propositions and causation diagrams were drawn. The subsequent case study results were compared with the typical case study and further analyses made using case summaries and explanation building. 


\section{RESULTS OF CASE STUDIES}

\section{Case Study I}

Case Study I was a stadium project constructed to host the 2010 FIFA World cup in South Africa. It was selected because it represented a typical project with time and cost overruns.

The client, a local authority working in collaboration with the central government and the Federation International de Football Association (FIFA), employed a project manager and other consultants who in turn helped to appoint a contractor through competitive tendering.

Six respondents were interviewed: (1) The client's representative, (2) The project manager (procurement), (3) Project manager (supervision), (4) Project manager (contractor), (5) Lead quantity surveyor and (6) Electronics consultant. Documentary analysis was based on materials provided by the client, the project manager and specialist books and articles written on the project.

\section{Causes of time and cost overruns}

The results are captured in Table 2, identifying six principle factors and their environment of origin.

Table 2. Case Study I: Root Cause of Time and Cost Overruns

\begin{tabular}{|c|c|c|}
\hline Factor & Reasons & Environment \\
\hline 1. Location problems: & & External \\
\hline $\begin{array}{l}\text { (a) Resistance from public } \\
\text { golf club and local } \\
\text { community } \\
\text { (b) Resistance from golf } \\
\text { fraternity } \\
\text { (c) Environmental Impact } \\
\text { Assessment (EIA) rejection } \\
\text { of chosen location } \\
\text { (d) Different ground } \\
\text { conditions of EIA location }\end{array}$ & $\begin{array}{l}\text { 1. Community fears of the impact of } \\
\text { the project: } \\
\text { (a) The area will be flooded by } \\
\text { spectators } \\
\text { (b) Value of the properties would } \\
\text { be downgraded } \\
\text { 2. Historic significance of location } \\
\text { 3. Found the alternative location more } \\
\text { suitable } \\
\text { 4. Design had concentrated on } \\
\text { original location } \\
\text { 5. New location subsoil conditions } \\
\text { different from the first location }\end{array}$ & \\
\hline
\end{tabular}


Table 2. (continued)

\begin{tabular}{|c|c|c|}
\hline Factor & Reasons & Environment \\
\hline $\begin{array}{l}\text { 2. Pressure from local } \\
\text { community and media } \\
\text { against the project }\end{array}$ & $\begin{array}{l}\text { 1. Public fears of project impact: } \\
\text { (a) Mar tourist attractions in the } \\
\text { area } \\
\text { (b) Mar location's historical } \\
\text { significance } \\
\text { (c) Project would be costly when } \\
\text { there are other needy causes } \\
\text { (d) The project cost would } \\
\text { bankrupt the city } \\
\text { (e) Effect of Afrophobia pressure } \\
\text { from Western countries on South } \\
\text { Africa's ability to host World Cup } \\
\text { 2. Threat of court action }\end{array}$ & External \\
\hline 3. Client's insufficient budget & $\begin{array}{l}\text { 1. Lack of experience in similar } \\
\text { projects } \\
\text { 2. Under-estimating project complexity } \\
\text { 3. Subtle pressure from the public } \\
\text { perception that project is costly }\end{array}$ & Organisation \\
\hline $\begin{array}{l}\text { 4. Under-estimating project } \\
\text { complexity }\end{array}$ & Lack of experience in similar projects & Project \\
\hline \multirow[t]{2}{*}{ 5. Procurement requirements } & $\begin{array}{l}\text { Longer process of statutory } \\
\text { requirements: }\end{array}$ & Organisation \\
\hline & $\begin{array}{l}\text { (a) Anti-corruption practices } \\
\text { (b) Competitive tendering }\end{array}$ & \\
\hline 6. FIFA/City requirements & New requirements & External \\
\hline
\end{tabular}

Grouping together the causes according to the environment they originate from gave insight showing that three out of six causes originated from the external environment, two out of six, from the organisation environment and one out of six from the project environment. From the research, most causes originated from the external environment followed by project environment and then organisation environment.

The results also revealed the various effects of the six factors on the management of the project as follows: (1) The project was moved from one location to another due to local community resistance and an EIA location change request which resulted in different ground conditions and reduction of consultants' available design production time, (2) Lower project budget, iconic design and fast contractor appointment due to public pressure, (3) Reduction in consultants' available design production time due to insufficient budget, (4) Insufficient budget due to under-estimating project complexity, (5) Longer procurement process due to procurement requirements and (6) Design changes, change in anticipated construction methods, acceleration and increased costs due to client induced changes. They show the effect of external factors in the external environment on both the project environment and the organisation environment giving us insights of how the overruns were incurred and the behaviour of the participants in response to these factors. 


\section{Discussions and implications}

The results showed that time and cost overruns were due to a combination of factors namely, location problems, community pressure and resistance, insufficient budget, underestimating project complexity and procurement requirements of the client and FIFA.

The findings show that time and cost overruns are not only caused by factors in the project and organisation environment, as discussed in the evolution and psycho-strategic theories but also by factors in the external or macro-environment. The root cause sprang from the external environment in line with the nature of large projects as most of the project management issues on large projects have much to do with external factors (Capka, 2004; Morris and Hough, 1987).

The dominating factor in the project environment was lack of project-specific experience which itself originated from the external environment due to few and far-spaced large projects in the macro project environment. It was equally true with the organisation environment factors, procurement requirements and FIFA/ city requirements. These were externally generated factors.

This suggests that the factors in the external environment affected both the project and organisation environment leading to time and cost overruns, yet project management confined itself to the project environment. The implication is that external environment management is critical to reducing time and cost overruns in large projects.

The most common effect found in most factors was the reduction of the consultants' available time to produce designs, which led to incomplete designs. This suggests that the factors behind time and cost overruns occur before incomplete designs or design changes. It also means that the recommendation often made by scholars for the client or consultants to complete the designs and avoid design changes would not address the real problem. The possible project management strategy to reduce time and cost overruns may lie in improving the project team's relevant experience and the management of the public to minimise resistance to projects.

It is theorised that the limited approach to the management of the project environment leaving out the external and organisation environments is a major handicap in the large project management strategy which results in time and cost overruns.

\section{Case Study II}

In Case Study II, the project team was in a state-owned enterprise (SOE) to build a $6 \times 800 \mathrm{MW}$ power plant in South Africa. The project team comprised the SOE employees and those of a partner organisation seconded to the project to provide construction management expertise. The project was led by a director who supervised contracts and construction managers for contract administration and supervision respectively. The project was broken down into various packages and contracted to several contractors with the main works, boilers and turbines, contracted to two contractors to design and construct complete with the attendant civil works. The project experienced time and cost overruns and the completion dates and estimates were changed several times (it was ongoing at the time of the research). The planned erection period of the turbines per unit was 25 months with a month of transition from one unit to the next for the six units. At the time of research, 
Unit 1 was 24.3 months late, yet its construction progress was $72 \%$ with the other units not yet started.

\section{Causes of time and cost overruns}

From the analysis of interviews and documentary evidence, time and cost overruns on this project were primarily driven by nine reasons as shown in Table 3 . There were 16 respondents interviewed who included the project director, construction and contract managers from both the client and the contractors.

Table 3. Case Study II: Root Cause of Time and Cost Overruns

\begin{tabular}{|c|c|c|}
\hline Factor & Reasons & Environment \\
\hline Insufficient budget & $\begin{array}{l}\text { 1. The pressure to solve the looming power } \\
\text { crisis } \\
\text { 2. Embarking on building two large } \\
\text { supercritical plants at same time } \\
\text { 3. Two funding moratoriums }\end{array}$ & Organisation \\
\hline Delayed project start & Delayed project approval & External \\
\hline Ground conditions & $\begin{array}{l}\text { 1. Started project without site identification } \\
\text { 2. The chosen site was hilly and required cut } \\
\text { and fill and piling }\end{array}$ & External \\
\hline $\begin{array}{l}\text { Pressure from public } \\
\text { and media }\end{array}$ & $\begin{array}{l}\text { 1. Public anxiety of power shortage } \\
\text { 2. Pressure from the media of power utility's } \\
\text { capacity to complete projects } \\
\text { 3. Pressure on power utility and project } \\
\text { executing team to complete projects }\end{array}$ & External \\
\hline $\begin{array}{l}\text { Under-estimation of } \\
\text { project complexity }\end{array}$ & $\begin{array}{l}\text { 1. Lack of experience of similar projects in } \\
\text { immediate past } \\
\text { 2. Underestimating project complexity } \\
\text { 3. Optimistic estimating based on past } \\
\text { experience }\end{array}$ & Project \\
\hline Procurement strategy & $\begin{array}{l}\text { 1. The strategy was chosen on a past } \\
\text { practice basis } \\
\text { 2. Lack of experience of similar projects in } \\
\text { immediate past }\end{array}$ & Organisation \\
\hline Lack of experience & $\begin{array}{l}\text { 1. Lack of similar projects in the country } \\
\text { 2. Loss of skilled manpower due to lack of } \\
\text { projects }\end{array}$ & Project \\
\hline Lack of preparation & $\begin{array}{l}\text { 1. Delayed project start, lack of time } \\
\text { 2. Lack of experience of similar projects in } \\
\text { immediate past } \\
\text { 3. Optimistic estimating based on } \\
\text { experience }\end{array}$ & Organisation \\
\hline Productivity problems & $\begin{array}{l}\text { 1. Inexperienced workforce } \\
\text { 2. Outsourcing of work } \\
\text { 3. Shifting organisation culture } \\
\text { 4. Cultural dynamics } \\
\text { 5. Package interface problems }\end{array}$ & Project \\
\hline
\end{tabular}


Due to pressure of looming power deficits, the client embarked upon two large supercritical plants concurrently leading to an insufficient budget and ultimately in lack of funds. Furthermore, the client lacked project-specific experience and underestimated the project complexity.

Project start was delayed by the government due to policy and when approved, there was reduced time for the client to plan and construct the projects. With combined pressure of dwindling reserves and public criticism, the client opted to use a shorter procurement route with the consequential ill-defined packages, access problems and poor project preparation. Similar to Case Study I, public pressure and project start delay affected the management of the project.

As in Case Study I, the overruns originated from the external environment (as shown in Table 3). The drivers were pressure from the public, project start delays by the government and lack of project-specific experience by the client and project team due to lack of construction of power plant projects for 50 years in the country.

This case study confirmed the results in Case Study I that overruns were caused by combined factors from the external environment. The major drivers were the project team's lack of project-specific experience and, insufficient preparation due to pressure from the public and a delayed project start.

\section{Case Study III}

Case Study III was the second literal replication study of a project team working in a large public-private high-speed passenger rail project in South Africa. The project consisted of the construction of a rail system of about $80 \mathrm{~km}$ long to service 10 stations. The project structure shows a special organisation was appointed which later appointed and supervised a turnkey contractor and an operations management contractor.

At the time of the study, the project had been completed. A total of four representatives were identified and interviewed: client's representative, chief executive officer (concessionaire), chief executive officer (turnkey contractor) and technical executive (concessionaire).

\section{Causes of time and cost overruns}

There were eight principal reasons for the occurrence of time and cost overruns on this project as shown in Table 4.

There were multiple effects of factors upon others eventually leading to time and cost overruns. For instance, the insufficient lower budget led to a delay in project start, reduction and change in project scope which eventually led to design changes and construction complications.

Thus, the two case studies positively showed that overruns originated from the external environment affecting both the organisation and project environments. Often, project participants managed projects by mitigating the effects of plans and strategies set in the external and organisation environments of which they had no part in formulating. 
Table 4. Case Study III: Root Cause of Time and Cost Overruns

\begin{tabular}{|c|c|c|}
\hline Factor & Reasons & Environment \\
\hline Delay to start the project & The concession negotiations took longer & Project \\
\hline $\begin{array}{l}\text { Land acquisition } \\
\text { problems }\end{array}$ & $\begin{array}{l}\text { The land acquisition process took longer } \\
\text { due to court cases and negotiations } \\
\text { bottlenecks }\end{array}$ & External \\
\hline $\begin{array}{l}\text { Influence of the World } \\
\text { Cup }\end{array}$ & $\begin{array}{l}\text { The World Cup became a completion } \\
\text { date milestone to the project }\end{array}$ & External \\
\hline Water in the tunnel & $\begin{array}{l}\text { Water levels in the tunnel were higher than } \\
\text { planned as well as that the contractor was } \\
\text { asked to redo the section for not following } \\
\text { the client's specifications }\end{array}$ & Project \\
\hline $\begin{array}{l}\text { Client's insufficient } \\
\text { budget }\end{array}$ & $\begin{array}{l}\text { The client lacked experience in the } \\
\text { construction of rapid passenger railways } \\
\text { and there was sustained pressure from the } \\
\text { public }\end{array}$ & Organisation \\
\hline Environmental concerns & $\begin{array}{l}\text { The project had higher than average } \\
\text { environmental requirements }\end{array}$ & External \\
\hline $\begin{array}{l}\text { Pressure and public } \\
\text { resistance }\end{array}$ & $\begin{array}{l}\text { There was concern from the public on } \\
\text { the impact of the project especially } \\
\text { displacement of people along the route } \\
\text { and that the cost would be too high for } \\
\text { the province }\end{array}$ & External \\
\hline Design changes & $\begin{array}{l}\text { The geotechnical conditions along a } \\
\text { section of the route were different from } \\
\text { the anticipated }\end{array}$ & Project \\
\hline
\end{tabular}

\section{Theoretical Replication Studies}

The two other case studies were chosen because they presented projects that were completed within time and budget similar to the study by Giezen (2012) of a deviant case (Harding, 2013) for theoretical replication.

The analysis from the recorded interviews and documentary evidence was directed at the following specific questions: (1) Were the participants experienced? (2) Was there a lack of time? (3) Was there resistance to the project? (4) Were there design changes? (5) Was the budget insufficient? and (6) Was the project completed within time and cost planned at tender?

\section{Case Study IV}

Case Study IV was of a river dam project carried out by the Department of Water and Sanitation which, on a similar previous project, had set up a semi-autonomous department to finance and manage the project. In partnership with an experienced Canadian organisation, this department had managed the project gaining corporate and individual professional experience from this project. They set up construction and project management systems which they used in future projects. 
On the case study project, the project implementer was appointed to source for finances and manage the project on Department of Water and Sanitation's behalf and hand it over to the local municipality upon completion. The project was completed on time and within budget and handed over to the municipality.

Using purposive and snowball sampling, four respondents for the case study were interviewed. These were the project manager, the project director, the concrete manager and the technical manager. From the interview transcripts and documentary evidence, using the questions discussed earlier, the following were the results on how the project was managed:

\section{Experience}

The client had on an earlier similar project, set up a national semi-autonomous institution to finance and manage their projects. This implementation manager over the years acquired the necessary experience to finance, design and construct large infrastructure. They carried out the case study project effectively due to the experience acquired over the years.

The consultants and the contractor were equally experienced in this type of work having worked on the previous large dam project. The project manager, on behalf of the implementation manager, set up project management and communication processes and procedures, including a detailed design development/construction installation strategy to avoid information delays.

\section{Lack of time}

Time limitation was not a factor on this project and the client did not set a completion date. The project start was not delayed and, the project, funding and environmental approvals had all been managed when construction started. They even met the impounding date successfully.

\section{Community resistance}

There was community resistance on this project. It was driven by the community's fear of the project's impact on the environment and public morals based on previous project experience. The resistance was managed when the project team appointed an influential personage to engage the community.

\section{Design changes}

There were no major design changes on this project due to: extensive feasibility studies before design commencement, experience and preparation of the client and consultant and identification and development of feasibility concepts based on the chosen location.

The results show that identification of the project site, extensive feasibility studies before the commencement of design, client and consultant experience and preparation were crucial factors in avoiding design changes on the project. 


\section{Completion within time and cost}

The budget was sufficient. The final contract price was even lower than the planned project expenditure. The project was ultimately completed within the time and cost planned at tender.

\section{Discussion and implications}

The results show that the factors found to have led to time and cost overruns on the overrunning projects were missing in this project. Furthermore, factors that led to the project's successful implementation were that the client and the project members were experienced in the project type, had carried out extensive studies before embarking on the project and set up project management processes.

The results also showed that a public project could be successfully implemented without time and cost overruns rejecting the rival explanation of success being dependent on whether a project is public or private. Furthermore, the results showed the influence of the involvement of the project implementation manager in the formulation and execution of the project. Their involvement from the client's organisation environment to the project environment and their involvement in other projects in the external environment was important in the successful delivery of the project. This suggests that a successful strategy in the management of large projects potentially needs to incorporate the involvement of an organisation with gained experience of several projects in the external environment to help the client in the organisation environment as well as in the project environment to formulate and execute projects.

\section{Case Study V: The Commercial Building Project}

Case Study $V$ was a private commercial building project that was completed within the planned time and cost. The project comprised the construction of a 32-floor commercial and office space in South Africa. The client, an experienced developer of similar projects, employed an experienced project development manager to manage the design and construction process on their behalf. The development manager employed consultants and contractors to carry out the work.

Purposive sampling was used to select the respondents, ensuring that a representative from the client, consultants and the contractor were interviewed to gain a holistic understanding of the phenomenon under study. A total of nine respondents were identified and interviewed. These included development managers, project managers (consultant and contractor), quantity surveyor, mechanical and electrical engineers and project facade engineer.

\section{Experience}

Similar to the dam project, the client, consultants and the contractor were experienced in the type of project. The client employed a project development manager who was responsible for all their projects at a national level. They had a structured approach to managing the project processes such as communication, meetings, reporting cycles, rules and regulations and approach to variation management. 


\section{Lack of time}

The project had a fixed completion date because the client wanted to benefit from an early occupation tax incentive. The contractor agreed, overlooking the city's inclement weather. The pressure from the client which was also pressured from the government incentive policy affected the decision making in the project team. This confirms what was observed in the overrunning case studies of the effect of pressure on the project team.

\section{Community resistance}

There was community resistance on this project as well. As noted by scholars, large projects have extensive impacts on the community and country (Capka, 2004; Merrow, 2011; Morris and Hough, 1987). Using consultants and the involvement of the contractor, the project team managed the resistance. The experience of the project participants and the preparation for the project was instrumental in the resolution of the resistance.

\section{Design changes}

There were few design changes on the project and these were mostly on request of the client. This was due to the completed design concept, the experience and preparation of the project team.

\section{Completion within time and cost}

The project was completed within time and cost. The main reasons were the experience of the client and the project team, the involvement of the project development manager, the project manager, other consultants and the contractor. Other reasons included teamwork and project team commitment to deliver within time and cost, careful budgeting, structured approach to project management and management of all required project permits before the commencement of construction.

\section{DISCUSSION AND IMPLICATIONS FOR MANAGEMENT OF LARGE PROJECTS}

The results showed that most of the factors that led to time and cost overruns on the overrunning case studies were missing on this project. This was due to projectspecific experience of the client, development manager, consultants and the contractor. There was a lack of time and community resistance on this project, but these were successfully managed and did not affect the project start and project delays.

As in Case Study IV, this project was successfully delivered primarily due to the experience and commitment of the client and the project team. The project development manager's influence was crucially important to the successful delivery of the project. This organisation was appointed nationally to manage all projects on behalf of the client. This enabled them to gain considerable experience in planning and executing infrastructure projects, like the implementation manager 
in Case Study IV. The development manager was involved in the formulation of the project from the organisation environment to the project environment.

This confirms the results from both the non-overrunning and overrunning projects that the involvement of an organisation with gained experience of projects in the external environment to help the client in the organisation environment and in the project environment to formulate and execute projects, is important for the successful delivery of projects. It further confirms the theory proposed earlier that the limited approach to managing the project environment excluding the external and organisation environments is a major factor that leads to time and cost overruns in large projects.

A model of overrun causation is shown in Figure 1 which shows that factors in the external environment are the root of overruns in large projects. The model also shows the ripple effect on subsequent environments of actions and unattended to matters.

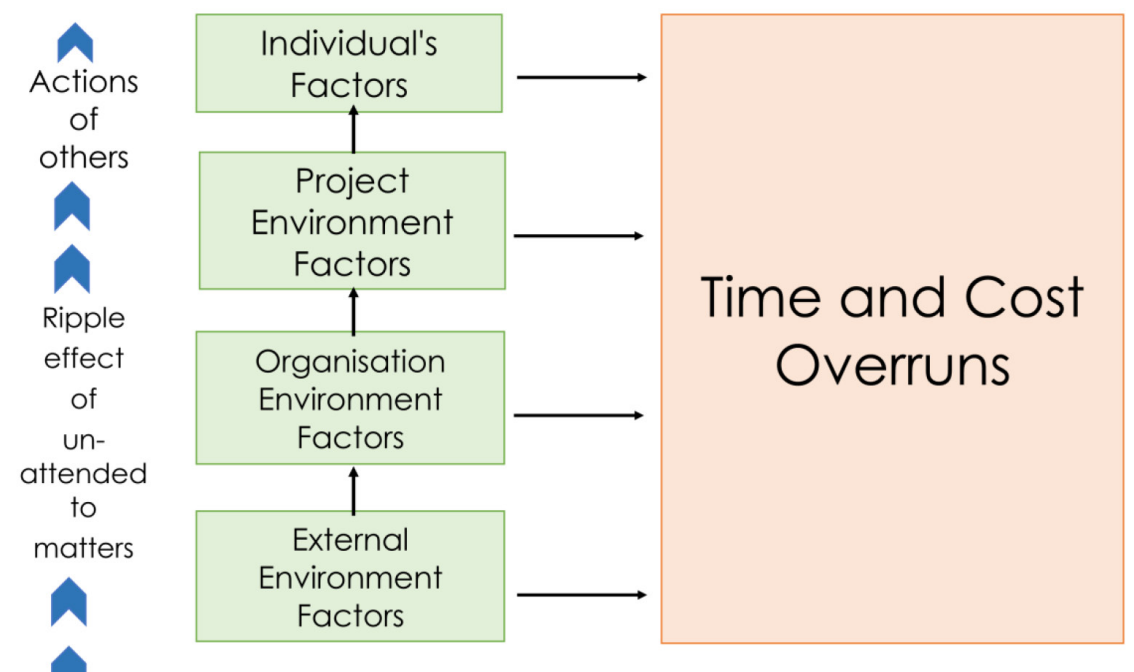

Figure 1. The Time and Cost Overruns Causation Model

\section{CONCLUSION}

The results from the typical and literal replication case studies showed that projects incurred time and cost overruns due to a combination of factors that originated from the external environment.

The root cause of time and cost overruns were found to be lack of projectspecific experience, decisions in the past in the external and organisation environments, community resistance and pressure, delayed project start, insufficient client budgets and, procurement requirements of the client. The results also showed that the project team's approach was to manage the project environment, without sufficient attention to the management of the organisation and external environments. These findings are elaborated upon below. 
The lack of experience was due to the lack of specific projects in the country at the macro environment level leading to loss of capacity of both consultants and contractors at the microproject environment level. This supports the research carried out by Groenveld (2006) and Ofori, Hindle and Hugo (1996) who pointed out the knowledge and experience loss in the South African construction industry due to cyclical and low work flows. This affected the management and delivery of projects leading to insufficient budgets and choice of procurement strategies.

Decisions in the past in the external environment, as well as the higher levels of the organisation environment, affected the management of projects at project environment level often leading to delayed project start and consequently reduced design time for consultants. The effect of this was the use of procurement short-cuts and consequential time and cost overruns.

Community resistance and pressure, which are external environment factors, affected both the organisation and project environment leading to delayed project start, insufficient budgets (to meet their criticism against expensive projects) and procurement short cuts resulting into redesigns, reworks, request for additional project funding and, project time and cost overruns.

The results from the theoretical replication studies, however, showed that by using experienced project implementers, not only in the project environment but also in the external and organisation environments, improved the delivery of the projects and reduced the tendency to have time and cost overruns. The results confirmed the theory that the limited approach to the management of the project environment by excluding the external and organisation environments is a major handicap in a large project management strategy. Integrated view theory of overruns causation is proposed in the article which explains overruns on large projects are caused by a combination of factors in the external, organisation and project environments.

It is therefore proposed that to reduce time and cost overruns on large projects, it is necessary to have an integrated strategy that involves the management of the project, the organisation and external environments. This can be done through a country-wide central large project implementation centre to coordinate numbers of projects and assist to manage the implementation of projects at the macro and micro level, to address the lack of project-specific experience and build capacity (detailed elaboration of the strategy is a subject of another article).

This research supports the work of Morris and Geraldi (2011) who found that project performance is done at three levels, the technical, strategic and institutional levels. It was found that a large project is performed in three environments, the external, organisation and project environments and that to reduce time and cost overruns, integrated management of all the three environments is necessary.

The contribution of this research is that it gives a detailed understanding of how time and cost overruns occur on large projects and provides an integrated overrun causation theory to add to the evolution and psycho-strategy theories. In contrast to many studies which focus on identifying significant and singular factors, for instance, consider the recent work of Mushayi et al. (2018), using case studies, the current research has shown that the root cause of the overrun phenomenon in large projects springs from the external environment and later affects the organisation and project environments suggesting that an effective strategy to reduce overruns in large projects requires not only the management of the 
project and organisation environments but also the management of the external environment.

It is recommended that further research explore the relationships amongst the causation factors and the influence of project management and its professionals on the external environment.

The study was limited to five case studies in South Africa, but it is believed the results will be found of benefit to other regions. The article contributes to the knowledge on the theory of overrun causation and the improvement of the management of large projects.

\section{ACKNOWLEDGEMENTS}

All the project participants who made time available to provide information during interviews are acknowledged for their support.

\section{REFERENCES}

Ahiaga-Dagbui, D.D., and Smith, S.D. (2014). Dealing with construction cost overruns using data mining. Construction Management and Economics, 32(7/8): 682694. https://doi.org/10.1080/01446193.2014.933854.

Ahiaga-Dagbui, D.D., Smith, S.D., Love, P.E.D. and Ackermann, F. (2015). Spotlight on construction cost overrun research: Superficial, replicative and stagnated. In A.B. Raiden and E. Aboagye-Nimo (eds.), Proceedings of 31st Annual ARCOM Conference. Lincoln, UK: Association of Researchers in Construction Management (ARCOM).

AlSehaimi, A., Koskela, L. and Tzortzopoulos, P. (2013). The need for alternative research approaches in construction management: The case of delay studies. Journal of Management in Engineering, 29: 407-413. https://doi.org/10.1061/ (ASCE)ME.1943-5479.0000148.

Ameh, O.J., Soyingbe, A.A. and Odusami, K.T. (2010). Significant factors causing cost overruns in telecommunication projects in Nigeria. Journal of Construction in Developing Countries, 15(2): 49-67.

Anderson, D.K. and Merna, T. (2003). Project management strategy: Project management represented as a process based set of management domains and the consequences of project management strategy. International Journal of Project Management, 21: 387-393. https://doi.org/10.1016/\$02637863(02)00087-X.

Cantarelli, C., Molin, E.J.E., Wee, B.V. and Flyvbjerg, B. (2012). Characteristics of cost overruns for Dutch transport infrastructure projects and the importance of decision to build and project phases. Transport Policy, 22: 49-56. https://doi. org/10.1016/j.tranpol.2012.04.001.

Capka, J.R. (2004). Mega-projects are a different breed. Public Roads, July/August.

Dahl, R.E., Lorentzen, S., Oglend, A. and Osmundsen, P. (2017). Pro-cyclical petroleum investments and cost overruns in Norway. Energy Policy, 100: 6878. https://doi.org/10.1016/j.enpol.2016.10.004. 
Eizakshiri, F., Chan, P.W. and Emsely, M. (2011). Delays, what delays? A critical review of the literature on delays in construction. In C. Egbu and E.C.W. Lou (eds.), Proceedings 27th Annual ARCOM Conference. Bristol, UK: Association of Researchers in Construction Management (ARCOM), 839-848.

Fellows, R. and Lui, A. (2008). Research Methods for Construction. Chichester: Blackwell.

Flyvbjerg, B. (2011). Over budget, over time, over and over again. Managing major projects. In P.W.G. Morris and J.K. Pinto (eds.), The Oxford Handbook of Project Management. Oxford: Oxford University Press, 321-344.

Frimpong, Y., Oluwoye, J. and Crawford, L. (2003). Causes of delay and cost overruns in construction of groundwater projects in a developing country: Ghana as a case study. International Journal of Project Management, 21: 321-326. https://doi.org/10.1016/S0263-7863(02)00055-8.

Giezen, M. (2012). Keeping it simple? A cases study into the advantages and disadvantages of reducing complexity in mega project planning. International Journal of Project Management, 30: 781-790. https://doi.org/10.1016/j. ijproman.2012.01.010.

Groenveld, G.D. (2006). The way forward for the South African construction industry: An analysis with project management solutions. MBA diss., Stellenbosch University.

Harding, J. (2013). Qualitative Data Analysis from Start to Finish. London: Sage.

Kaliba, C., Muya, M. and Mumba, K. (2009). Cost escalation and schedule delays in road construction projects in Zambia. International Journal of Project Management, 27: 522-531. https://doi.org/10.1016/j.jpproman.2008.07.003.

Le-Hoai, L., Lee, Y.D. and Lee, J.Y. (2008). Delay and cost overruns in Vietnam large construction projects: A comparison with other selected countries. KSCE Journal of Civil Engineering, 12(6): 367-377. https://doi.org/10.1007/s12205008-0367-7.

Lim, C.S. and Mohamed, M.Z. (1999). Criteria of project success: An exploratory reexamination. International Journal of Project Management, 17(4): 243-248. https://doi.org/10.1016/S0263-7863(98)00040-4.

Lin, Y. and Lui, S. (2011). Small and large projects: Their dynamics and which ones to take.Kybernetes, 40(9): 1354-1372. https://doi.org/10.1108/03684921111169431.

Love, P. E. D., Smith, J., Simpson, I., Regan, M. and Olatunji, O. (2014). Understanding the landscape of overruns in transport infrastructure projects. Environment and Planning B: Planning and Design, 41: 1-20.

Love, P.E.D., Ahiaga-Dagbui, D.D. and Irani, Z. (2016). Cost overruns in transportation infrastructure projects: Sowing the seeds for a probabilistic theory of causation. Transportation Research Part A, 92: 184-194. https://doi. org/10.1016/j.tra.2016.08.007.

Memon, A.H., Rahman, A.I., Abdullah, M.R. and Azis, A.A.A. (2014). Factors affecting construction cost performance in project management projects: Case of MARA large projects. International Journal of Civil Engineering and Built Environment, 1 (1): 30-35.

Merrow, E.W. (201 1). Industrial Megaprojects: Concepts, Strategies and Practices for Success. Hoboken, NJ: John Wiley and Sons.

Morris, P.W.G and Geraldi, J. (2011). Managing the institutional context for projects. ProjectManagement Journal, 42(6):20-32. https://doi.org/10.1002/pmj.20271.

Morris, P.W.G. and Hough, G.H. (1987). The Anatomy of Major Projects: A Study of the Reality of Project Management. Chichester: John Wiley and Sons. 
Muianga, E.A.D., Granja, A.D. and Ruiz, J.A. (2014). Influence factors on cost and time overruns in Mozambicans construction projects: Preliminary findings. Proceedings: 5th International Conference on Engineering, Project and Production Management. Port Elizabeth, South Africa: Nelson Mandela Metropolitan University, 10-21.

Mukuka, M., Aigbavboa, C. and Thwala, W. (2015). Effects of construction project schedule overruns: A case of the Gauteng Province, South Africa. Procedia Manufacturing, 3: 1690-1695. https://doi.org/10.1016/j.promfg.2015.07.989.

Murray, M. (2010). An investigation into programme management risks. PhD diss., University of Witwatersrand.

Mushayi, V., Botha, B., Anderdoff, C., Cumberledge, R. and Abey, M. (2018). Cost overruns and their impact in the business of construction. Proceedings: The Twelfth Built Environment Conference. Penhill Estate, South Africa: Association of Schools of Construction of Southern Africa, 277-287.

Ofori, G., Hindle, R. and Hugo, F. (1996). Improving the construction industry in South Africa: A strategy. Habitat International, 20(2): 203-220. https://doi. org/10.1016/0197-3975(95)00056-9.

Ramanathan, C., Narayanan, S.P. and Idrus, A.B. (2012). Construction delays causing risks on time and cost: A critical review. Australasian Journal of Construction Economics and Building, 12: 37-57. https://doi.org/10.5130/AJCEB.v12i1.2330.

Rosenfield, Y. (2013). Root-cause analysis of construction-cost overruns. Journal of Construction Engineering and Management, 140(1): 04013039. https://doi. org/10.1061/(ASCE)CO.1943-7862.0000789.

Senouci, A., Ismail, A. and Eldin, N. (2016). Time delay and cost overrun in Qatari public construction projects. Procedia Engineering, 164: 368-375. https://doi. org/10.1016/j.proeng.2016.11.632.

Sweis, G. (2013). Factors affecting time overruns in public construction projects: The case of Jordan. International Journal of Business and Management, 8(23): 120-129. https://doi.org/10.5539/ijbm.v8n23p120.

Tai, S.W. and Anumba, C.J. (2009). A survey on communications in large-scale construction projects in China. Engineering, Construction and Architectural Management, 16(2): 136-149. https://doi.org/10.1108/09699980910938019.

Whittaker, B. (1999). What went wrong? Unsuccessful information technology projects. Information Management and Computer Security, 7(1): 23-29. https://doi.org/10.1108/09685229910255160.

Yin, R.K. (2014). Case Study Research: Design and Methods. 5th Ed. Thousand Oaks, CA: Sage. 